\title{
Investigation of Turn-To-Turn Closures of Stator Windings to Improve the Diagnostics System for Induction Motors
}

\author{
Gubarevych O., Goolak S., Daki O., Tryshyn V. \\ State University of Infrastructure and Technologies \\ Kyiv, Ukraine
}

\begin{abstract}
The efficiency of using three-phase asynchronous electric motors with a squirrel-cage rotor in the transport sector depends on increasing the level of their reliability, which is possible due to the constant improvement of existing and the development of new diagnostic methods of high reliability. The most labor-consuming and difficult is the possibility of diagnostics and differentiation of turn-toturn closures of the stator winding. The aim of the work is to establish the nature of the manifestation, influence on energy indicators and determine the diagnostic parameters of turn-to-turn closures on one and simultaneously on two phases of the stator winding of an induction motor using mathematical modeling methods. This goal was achieved through a set of studies using a refined mathematical model of an asynchronous motor, which allows you to create asymmetry of the stator windings, simulate turn-to-turn connections on one phase and simultaneously on two phases in various combinations. The most significant result of the work is the establishment of the dependences of the pulsations of the electromagnetic moment, the unbalance coefficient of the stator phase currents and the energy characteristics from the turn-to-turn short-circuits of the phases of the stator windings. The significance of the results obtained consists in establishing the dependences of the manifestation of various types of damage to the phases of the stator winding necessary for choosing a method for diagnosing turn-to-turn faults in the stator windings when building an effective diagnostic system for asynchronous motors as part of transport infrastructure drives.
\end{abstract}

Keywords: transport infrastructure, diagnostics, asynchronous motor, mathematical modeling, turn-toturn circuit, phase, winding, stator, ripple, torque.

DOI: https://doi.org/10.52254/1857-0070.2021.2-50.02

UDC: 621.313.333.2

Investigarea scurtcircuitelor între spine ale înfășurărilor statorice cu scopul perfecționarea sistemelor de diagnosticare a motoarelor cu inducție

Gubarevici O.V., Gulac S.A., Dachi E.A., Trișin V.V.

Universitatea de Stat a Infrastructurei și tehnologiilor

Kyev, Ucraina

Rezumat. Motoarele asincrone trifazate cu colivie de veveriță sunt unele dintre cele mai comune tipuri de mașini electrice utilizate în sectorul transporturilor. Eficiența utilizării acestor motoare electrice depinde de creșterea nivelului de fiabilitate a acestora, ceea ce este posibil datorită îmbunătățirii permanente a metodelor existente și dezvoltării de noi metode de diagnosticare cu fiabilitate înaltă. Scopul lucrării este de a stabili natura manifestării, influența asupra indicatorilor energetici şi de a determina parametri de diagnosticare a scurtcircuitelor între spine unei fazei şi simultan pe două faze ale înfăşurării statorice a motoarelor asincrone ale mecanismelor de transport folosând metodele de modelarea matematică. Acest obiectiv a fost realizat prin efectuarea unui set de studii asupra modelul matematic rafinat al motorului de inducție, care face posibilă crearea asimetriei înfăşurărilor statorului, simulând scurtcircuit între spine pe o singură fază şi simultan pe două faze în diferite combinații. Simularea a fost efectuată pentru un stator nedeteriorat, apoi la simularea închiderii virajelor, mai întâi doar pe o fază și apoi închiderea simultană pe două faze ale înfășurării statorului în diferite combinații. Cel mai semnificativ rezultat al lucrării este stabilirea dependențelor de pulsații ale momentului electromagnetic, coeficientul de dezechilibru al curenților de fază statorici și caracteristicile energetice de la scurtcircuitelor între spine ale înfășurărilor statorului.

Semnificația rezultatelor obținute constă în stabilirea dependențelor de manifestare a diferitelor tipuri de deteriorare a fazelor înfășurării statorului, care sunt necesare pentru alegerea unei metode pentru diagnosticarea defecțiunilor spinelor în înfășurările statorului atunci când se construiește un sistem eficient de diagnosticare pentru motoare asincrone ca parte a unităților de infrastructură de transport.

Cuvinte-cheie: infrastructură de transport, diagnosticare, motor asincron, modelare matematică, scurtcircuit între spine, fază, înfăşurare, stator, ondulare, cuplu.

(c) Gubarevych O., Goolak S., Daki O.,

Tryshyn V. 2021 


\author{
Исследование межвитковых замыканий обмоток статора \\ для усовершенствования систем диагностики асинхронных двигателей \\ Губаревич О.В., Гулак С.А., Даки Е.А., Тришин В.В. \\ Государственный университет инфраструктуры и технологий \\ Киев, Украина
}

Аннотация. Трехфазные асинхронные двигатели с короткозамкнутым ротором являются одними из наиболее распространенных типов электрических машин, применяемых в транспортной сфере. Эффективность использования этих электродвигателей зависит от повышения уровня их надежности, что возможно за счет постоянного усовершенствования существующих и разработки новых диагностических методов высокой достоверности. Наиболее трудоемким и сложным остается возможность диагностики и дифференцирования межвитковых замыканий обмотки статора. Целью работы является установление характера замыкания, влияния его на энергетические показатели двигателя и определение диагностических параметров межвитковых замыканий на одной и одновременно на двух фазах обмотки статора асинхронных двигателей транспортных механизмов с использованием методов математического моделирования. Поставленная цель была достигнута за счет проведения комплекса исследований на уточненной математической модели асинхронного двигателя, позволяющей создавать несимметричность обмоток статора, имитирующую межвитковые замыкания на одной фазе и одновременно на двух фазах в различных комбинациях. В качестве объекта исследований использован асинхронный двигатель с короткозамкнутым ротором мощностью 11,0 кВт с известными паспортными параметрами. Методика проведения исследований включает изучение влияния различных видов межвитковых замыканий на электрические, механические и энергетические показатели. Моделирование проводилось для неповрежденного статора, затем при имитации замыкания витков сначала только на одной фазе и затем одновременного замыкания на двух фазах обмотки статора в различных комбинациях. Наиболее существенным результатом работы является установление зависимостей пульсаций электромагнитного момента, коэффициента небаланса фазных токов статора и энергетических характеристик от межвитковых замыканий фаз обмоток статора. Значимость полученных результатов состоит в установлении зависимостей проявления различных видов повреждений фаз обмотки статора, необходимых для выбора метода диагностики межвитковых замыканий в обмотках статора при построении эффективной диагностической системы асинхронных двигателей в составе приводов транспортной инфраструктуры.

Ключевые слова: транспортная инфраструктура, диагностика, асинхронный двигатель, математическое моделирование, межвитковое замыкание, фаза, обмотка, статор, пульсации, момент.

\section{INTRODUCTION}

In order to ensure the efficient operation of the transport system it is necessary to improve its reliability. This requires its permanent development and perfection of the diagnostic methods and systems of the operative control in the current-state evaluation and prediction the period of unfailing service [1].

As the drive motors for the railway vehicles and auxiliary equipment both for the railway and water transport the asynchronous motors with a with a squirrel-cage rotor are extensively used.

The fault analysis of the asynchronous motors $[2,3]$ showed that about $15 \%$ of the total amount of this motor type failures occurs because of the inter-turn short-circuits in the stator phase windings. Hence, the complex approach to the study of the processes arising in the asynchronous motor at the inter-turn short-circuit are of primary importance to diagnose the faults of the kind.

The inter-turn short-circuits failure is the type of a fault that is most hard to be diagnosed. It leads to temperature rise in closed sites $[4,5]$, which ruins the insulation [6] and creates the drive emergency failures at the drive's long-term service [7].

In addition, the diagnosis complexity of the inter-turn short-circuits of the stator winding is increased by the fact that the external features of the defect can be similar to those of a number of other faults [8].

In this case, the creation of a more authentic diagnostic system necessitates a still further study of the consequences, which result from the stator windings faults, the creation of scientific bases according to the researches carried out and the prime items development of the integrated complex for reliability improvement of the transport infrastructure.

The researches of [9] showed that the analysis of arising the inter-turn short-circuit faults of different degree at a single phase of the stator winding of the asynchronous motor, exhibited the origin of substantial torque pulsations of the motor and asymmetry of stator phase currents. The torque pulsations are observed mainly in the idle-run mode. In addition, the fault of this kind 
increases the consumed power, decreases the emf and the motor power factor, reducing thus the motor energy indices.

The kind of failure of the asynchronous motor stator as the inter-turn short-circuit simultaneously on both stator windings, in practice can be met much scarcer, than on a single winding, however, it also needs a thorough study. To build up an efficient system of diagnostics you need first to select a diagnosis method and a method for the following development of the block of identification and differentiation of the failure. In its turn, the choice of the diagnosis method is based on the character of changes in the motor parameters at the occurrence of the inter-turn short circuit in the stator winding.

From the analysis of the effect of the turn-toturn short-circuit at a single stator phase on the characteristics of the asynchronous motor with a squirrel-cage rotor $[10,11]$ it follows that:

- the inter-turn short-circuit at a single stator phase increases the current in the faulted phase, which increases the average current of the stator, thus, enlarging the active power losses;

- the inter-turn short-circuit at the stator single phase increases the motor electromagnetic torque pulsations, which are mainly developed in the idle-run mode;

- the inter-turn short-circuit at the stator single phase increases the imbalance of the stator phase currents and, hence, leads to asymmetry of the stator rotating field.

It follows from the aforementioned that to detect, identify and differentiate the failure in question the thermal, electric, vibration and combined diagnosis methods can be used.

The thermal methods application are described in $[4,12]$. These methods are based on the heating temperature increase of the stator faulted phase winding under the inter-turn shortcircuit, which is the result of the increase in the current average value of this phase. However, the use of these methods is complex at identification and authentic differentiation of the type and degree of the stator winding failure, and, what is more, at the faultless time prediction of the electric motor operation.

The use of the diagnosis vibration methods $[13,14]$ make it possible to reveal the presence of failures in the stator winding according to the spectra of the vibration signals. The vibro-signal parameters enable to determine the presence of a number of failures as well by means of special sensors. However, for the control, precise identification of the defect detected, its development and prediction of the residual resource, a base of the vibration signals typical for various kinds and degrees of a fault of the stator winding is necessary. In addition, for the diagnostic systems in the drive configuration, the difficulty of the use of these methods is also in that the estimation of the torque pulsation in the presence of the failures of the stator winding develops mainly with the vibration diagnosis used in the idle-run mode [9], whereas the drive always works under the load.

The diagnostic electrical methods used for the practical issues are based on comparison of the values of the starter phase currents of the motor in its operating and faulted conditions. Thus, [15] compares the spectra of the starter currents of the operating motor and that with the stator winding failures. The spectra of the stator phase currents are studied [16, 17] in the steady condition for the operating motor and for the motor with the wavelet transforms of the stator phase currents in the steady mode for the operating motor and the faulted motor are presented [18, 19]. The finite element method was applied to study the changes in magnetic fluxes of the faulted and operating motor conditions [20]. The failure diagnosis of the stator winding is offered to be performed by way of comparison of these fluxes.

To estimate the degree of failure of the stator winding the modern techniques can be used [21], in which the decision block is realized using the neuron networks. Also the decision block can be realized by the use of mathematics of indistinct logics [22]. In addition, to apply the decision block it is necessary to have the data on the character of the change of a particular parameter and their effect on the motor efficiency.

To develop the diagnostic system with an authentic decision for the determination of a different kind and degree of a stator winding failure, a thorough research must be performed and the character of manifestation and modifying the parameters occurring upon the inter-turn short-circuit simultaneously on two phases of the stator winding must be studied. This phenomenon may also happen in the operational process of the asynchronous motor.

In this work, the complex approach is offered for the study of the effect of the inter-turn short circuit simultaneously on two phases of the asynchronous motor stator. The approach consists of performing the analysis of the influence and establishing the regularities of this 
defect on the parameters and characteristics of the motor and of comparison of the order of modification of the characteristics and parameters, depending on the combination degree of the inter-turn short-circuit in two phases of the windings. In [23] it is shown that the asynchronous motor integrated into various technological drives is fed from the nonsinusoidal nonsymmetric system of voltages. Power supply from the voltage system of such a kind induces the torque pulsation on the motor shaft. In this context, during this research the admissions are accepted on the supply system quality of the asynchronous motor, which is considered strictly symmetric, whereas the form of the voltages is sinusoidal.

The results of this work can be used for selection of the efficient method for plotting the diagnostic schemes of asynchronous motors with a squirrel-cage rotor and creation of the diagnostic complex as part of the transport drive.

The aim of this study is to establish the manifestation character, the effect on the power indices and the diagnostic parameters' determination of the inter-turn short circuits at a single and, simultaneously, at two phases of the stator windings of the asynchronous motor, using the methods for the mathematic modeling.

\section{MATHEMATIC MODEL CHOICE FOR THE PROCESSES' RESEARCH IN ASYNCHRONOUS MOTOR UPON THE INTER-TURN SHORT-CIRCUITS}

The asynchronous motor with a squirrel-cage rotor (an AIR132M4 11,0 kW model (Table 1)) was selected as the object for the research.
Selecting a model to study the inter-turn short circuits in the phases of the asynchronous motor stator winding, the possibility must be considered of creation nonsymmetrical fields in it, which takes place upon this failure, In [24, 25], the model is considered, in which the equations that describe the asynchronous motor operation, are written in a single-phase coordinate system. However, the use of this model makes it difficult to define certain parameters, particularly, the unbalance factor of the phase currents.

In the research of the inter-turn short-circuit in a single phase of the stator winding [9], the model is used (Goolak S., Gubarevych O., Yermolenko, E, Slobodyanyuk M, Gorobchenko, O. $\quad$ https://doi.org/10.15587/17294061.2020.199559), in which the nonsymmetry effect on characteristics like the inductance of the magnetization circuit and mutual inductance are taken into account according to the techniques, which is described in (Goolak S., Gerlici J., Tkachenko V., Sapronova S., Lack T., Kravchenko https://doi.org/10.26552/com.C.2019.2.24-31).

The work presented did not consider the phenomena such as the magnetic system saturation and rotor current displacement, which affect the dynamic of the model and the losses. However, they do not affect substantially the preset problem concerning the stator winding diagnostics.

Rating of asynchronous motor with a squirrel-cage rotor AIR $132 \mathrm{M4}$

\begin{tabular}{|l|c|c|c|}
\hline Parameter & Designation & $\begin{array}{c}\text { Unit of } \\
\text { measure }\end{array}$ & Value \\
\hline Nominal power on the shaft & $P_{n}$ & $\mathrm{~kW}$ & 11.0 \\
\hline Nominal phase voltage & $U_{n}$ & Volt & 220 \\
\hline Nominal frequency of feeding voltage & $f_{n}$ & $\mathrm{~Hz}$ & 50 \\
\hline Frequency of rotor spinning in idle-run mode & $n_{n . i d l e}$ & $\mathrm{rot} / \mathrm{min}$ & 1498 \\
\hline Load moment of idle run & $T_{\text {idle }}$ & $\mathrm{H} \cdot \mathrm{m}$ & 0.38 \\
\hline Active resistance of stator winding & $r_{I}$ & $\mathrm{Ohm}$ & 0.5 \\
\hline $\begin{array}{l}\text { Active resistance of rotor winding, reduced to stator } \\
\text { winding }\end{array}$ & $r_{2}^{\prime}$ & $\mathrm{Ohm}$ & 0.36 \\
\hline Reactive resistance of stator winding & $x_{I}$ & $\mathrm{Ohm}$ & 0.56 \\
\hline Frequency of rotor spinning in nominal mode & $n_{n}$ & $\mathrm{rot} / \mathrm{min}$ & 1450 \\
\hline Motor shaft torque moment & $T_{n}$ & $\mathrm{H} \cdot \mathrm{m}$ & 72,671 \\
\hline Motor momentum of inertia & $J$ & $\mathrm{~kg} \cdot \mathrm{m}^{2}$ & 0.04 \\
\hline
\end{tabular}


The accepted simulation model of an asynchronous motor with a squirrel-cage rotor is written in the "braked coordinates".

The systems of control that describe the motor operation look like as follows

$$
\left\{\begin{array}{c}
u_{s \alpha}=r_{s \alpha} \cdot i_{s \alpha}+d \psi_{s \alpha} / d t ; \\
u_{s \beta}=r_{s \beta} \cdot i_{s \beta}+d \psi_{s \beta} / d t ; \\
u_{s \gamma}=r_{s \gamma} \cdot i_{s \gamma}+d \psi_{s \gamma} / d t ; \\
-u_{r \alpha}=r_{r \alpha} \cdot i_{r \alpha}+\frac{d \psi_{r \alpha}}{d t}+\frac{\left(\psi_{r \beta}-\psi_{r \gamma}\right) \cdot p \cdot \omega_{r}}{\sqrt{3}} ; \\
-u_{r \beta}=r_{r \beta} \cdot i_{r \beta}+\frac{d \psi_{r \beta}}{d t}+\frac{\left(\psi_{r \gamma}-\psi_{r \alpha}\right) \cdot p \cdot \omega_{r}}{\sqrt{3}} ; \\
-u_{r \gamma}=r_{r \gamma} \cdot i_{r \gamma}+\frac{d \psi_{r \gamma}}{d t}+\frac{\left(\psi_{r \alpha}-\psi_{r \beta}\right) \cdot p \cdot \omega_{r}}{\sqrt{3}},
\end{array}\right.
$$

where $u$ is the voltage, $\mathrm{V} ; i$ is the current, $\mathrm{A} ; t$ is time, $\mathrm{s} ; r$ is the resistance, $\mathrm{Ohm} ; \psi$ is the flux linkage, $\mathrm{Wb} ; p$ is the number of pole pairs.

Indices of $\alpha, \beta, \gamma$ designate belonging to a certain phase; lower index $s$ is belonging to the stator phase; lower index $r$ is belonging to rotor phase; and $\omega_{r}$ is the rotor spinning frequency $\mathrm{rad} / \mathrm{s}$.

The flux linkages are described using the following system of differential equations

$$
\left\{\begin{array}{l}
\Psi_{s \alpha}=L_{s \alpha} \cdot i_{s \alpha}-0,5 \cdot M \cdot i_{s \beta}-0,5 \cdot M \cdot i_{s \gamma}+ \\
+M \cdot\left(i_{r \alpha}-0,5 \cdot i_{r \beta}-0,5 \cdot i_{r \gamma}\right) ; \\
\Psi_{s \beta}=L_{s \beta} \cdot i_{s \beta}-0,5 \cdot M \cdot i_{s u}-0,5 \cdot M \cdot i_{s \gamma}+ \\
+M \cdot\left(i_{r \beta}-0,5 \cdot i_{r \alpha}-0,5 \cdot i_{r \gamma}\right) ; \\
\Psi_{s \gamma}=L_{s \gamma} \cdot i_{s \gamma}-0,5 \cdot M \cdot i_{s \alpha}-0,5 \cdot M \cdot i_{s \beta}+ \\
+M \cdot\left(i_{r \gamma}-0,5 \cdot i_{r \alpha}-0,5 \cdot i_{r \beta}\right) ; \\
\Psi_{r \alpha}=L_{r \alpha} \cdot i_{r \alpha}-0,5 \cdot M \cdot i_{r \beta}-0,5 \cdot M \cdot i_{r \gamma}+ \\
+M \cdot\left(i_{s \alpha}-0,5 \cdot i_{s \beta}-0,5 \cdot i_{s \gamma}\right) ; \\
\Psi_{r \beta}=L_{r \beta} \cdot i_{r \beta}-0,5 \cdot M \cdot i_{r \alpha}-0,5 \cdot M \cdot i_{r \gamma}+ \\
+M \cdot\left(i_{s \beta}-0,5 \cdot i_{s \alpha}-0,5 \cdot i_{s \gamma}\right) ; \\
\Psi_{r \gamma}=L_{r \gamma} \cdot i_{r \gamma}-0.5 \cdot M \cdot i_{r \alpha}-0.5 \cdot M \cdot i_{r \beta}+ \\
+M \cdot\left(i_{s \gamma}-0.5 \cdot i_{s \alpha}-0.5 \cdot i_{s \beta}\right),
\end{array}\right.
$$

where $L$ is the total phase inductance, $\mathrm{H}$;

$M$ is the mutual inductance of the stator and rotor phases, $\mathrm{H}$.

The electromagnetic torque equation of the asynchronous motor is

$$
\begin{aligned}
& T_{E M}=\sqrt{3} \cdot M \cdot p \cdot\left[\left(i_{s \alpha} \cdot i_{r \gamma}+i_{s \beta} \cdot i_{r \alpha}+i_{s y} \cdot i_{r \beta}\right)-\right. \\
& \left.-\left(i_{s \alpha} \cdot i_{r \beta}+i_{s \beta} \cdot i_{r y}+i_{s y} \cdot i_{r u}\right)\right] / 2 .
\end{aligned}
$$

Equation of motion of the motor shaft with a single-mass mechanical system

$$
d \omega_{r} / d t=J \cdot\left(T_{E M}-T_{C}\right),
$$

where $T_{E M}$ is the moment of inertia of the rotating masses on the rotor shaft, $\mathrm{N} \cdot \mathrm{m} ; T_{C}$ is the static rotational moment on the rotor shaft, $\mathrm{N} \cdot \mathrm{m}$.

The mutual inductance is determined using the following formula

$$
M=2 \cdot L_{\mu} / 3,
$$

where $L_{\mu}$ is magnetization inductance.

Arranging the nonsymmetrical mode necessitates considering the mutual inductances' modifying. To determine the changes in the mutual inductances of the windings it is necessary to define the degree of the effect of changing in the alternative current impedance of one (or two) windings on the magnetic circuit inductance. In the work (Goolak S., Gerlici J., Tkachenko V., Sapronova S., Lack T., Kravchenko K. https://doi.org/10.26552/com.C.2019.2.24-31) the established connection is presented between the windings' inductances and their geometrical dimensions. Taking into account the uniformity of the air-gap and expressions for the phase inductances of scattering and phase mutual inductances, it was inferred that the inductances of scattering of each phase and mutual phase inductances can be written in the general form as follows

$$
L_{i j}^{X Y}=\left(L_{i j}^{\prime}\right)^{X Y} \cdot F\left(\alpha_{i j}, \varphi_{i j}\right),
$$

where $\left(L_{i j}^{\prime}\right)^{X Y}$ is the component, which depends on the winding geometrical dimensions; (the upper indices $X, Y$ can take $s$ or $r$ values and show which windings are considered: stator or rotor. The lower indices $i, j$ can take the values of $A, B, C$ and indicate the windings of which phases are considered); $F\left(\alpha_{i j}, \varphi_{i j}\right)$ is the component, which accounts for the angle shifts between the phase voltages $\alpha_{i j}$ and difference between the angle shifts of the phase currents of 
the stator and rotor $\varphi_{i j}$ of the corresponding windings in a symmetrical mode.

Since component $\mathrm{F}\left(\alpha_{i j}, \varphi_{i j}\right)$ relates to the symmetrical mode of the motor operation, to consider the connection between the inductances and the winding geometrical parameters it is feasible confining just to component $\left(L_{i j}^{\prime}\right)^{X Y}$, which is equal to

$$
\left(L^{\prime}\right)_{i j}^{X Y}=l_{\beta} \cdot Z_{i}^{X} \cdot Z_{j}^{Y} \cdot \frac{\pi}{n^{2}} \cdot \frac{r_{r}^{3}}{g} \cdot \mu,
$$

where $\mu$ is the magnetic permeability; $n$ is the number of periods of the current layer spatial distribution, which is relevant to the pairs of poles number $p ; g=r_{s}-r_{r}$ is the radial value of the air gap; $r_{s}$ is the stator radius; $r_{r}$ is the rotor radius; $Z_{j}^{X}=w_{j}^{X} / l$ is the linear density of the current layer conductor of a corresponding winding; $w_{j}^{X_{j}}$ is the number of turns of a corresponding stator winding phase; $l_{j}^{X}$ is the length of a corresponding winding; and $l_{\beta}$ is the axial length of the air gap.

The inductance of the motor magnetic circuit is defined using the following expression

$$
L_{\mu}=\sum_{i} \sum_{j} L_{i j}^{X Y}, \quad X \neq Y .
$$

Equation (8) is obtained in a general form after the substitution of inductance values from (7). This equation is reduced to the form of function, which accounts for the number of the phase winding turns, on which the complex resistance change is designed that simulates the inter-turns short circuits of a various degree.

The modification of the magnetic circuit inductance at a relevant change in the value of the winding complex resistance is estimated using the coefficient that is obtained taking into account (6) - (8) and is expressed in relative units

$$
k=L_{\mu}^{\prime} / L_{\mu} .
$$

The dependence of the modification of the magnetic circuit inductance coefficient on the value of the change in the phase complex resistance of the stator winding phase $(Z)$ is shown in Fig. 1.

Using the values of the magnetic circuit inductance for the symmetrical mode from Table 1 , with account for the coefficient of the winding complex resistance (9), the value of the magnetic circuit inductance is obtained for the preset conditions of occurrence the nonsymmetrical mode that is induced by the inter-turn shortcircuits.

$$
L_{\mu}^{\prime}=k \cdot L_{\mu}
$$

The value of the magnetic circuit inductance (obtained using (10) for the nonsymmetrical mode after the substitution into (5) allows us to define the value of the mutual inductance for the preset mode.

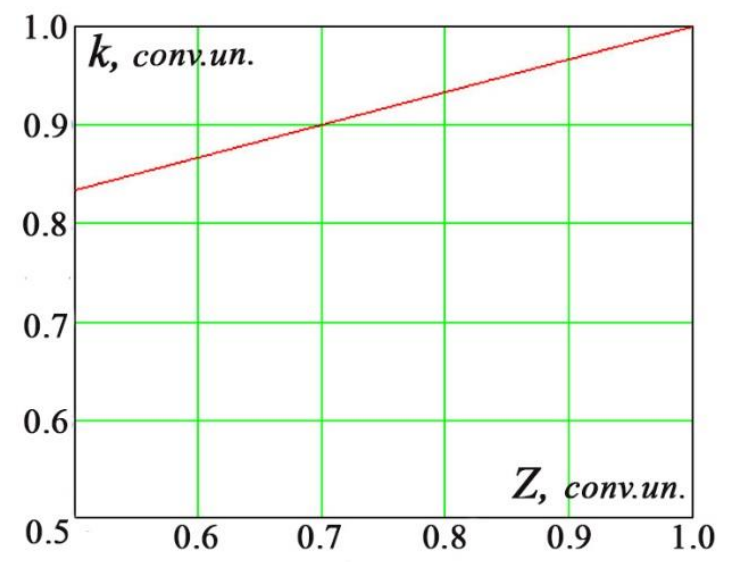

Fig. 1. Dependence of coefficient of magnetic circuit inductance change on the change in complex resistance of stator winding

The parameters' changes obtained were corrected using the simulation model.

During the asymmetric model creation, it is necessary to account for the following factors:

1. The most convenient parameter to determine the inter-turn short-circuit at a certain phase of the motor is the phase resistance.

2. As is seen from (7), the inductance of the phase scattering and mutual inductance are the square function of the number of turns.

3. The active resistance of the winding is defined using the following expression

$$
r_{s}=k_{r} \cdot \rho_{\theta} \cdot \frac{l_{\text {mean }} \cdot w}{q_{e . c .} \cdot n_{e . c .} \cdot a},
$$

where $k_{r}$ is the coefficient of increasing the active resistance of the winding phase from the thermal action of the enhanced current; $\rho_{\theta}$ is the specific resistance of the winding material upon the calculated temperature, Ohm; $l_{\text {mean }}$ is the average length of the winding turn, $\mathrm{m} ; w$ is the number of the winding turns; $q_{e . c}$ is the area of 
the cross section of the elementary conductor, $\mathrm{M}^{2} ; \quad n_{\text {e.c. }}$ is the number of the elementary conductors; $a$ the number of the parallel winding paths.

Hence, it follows that the active resistance of the stator phase is proportional to the number of the winding turns. For simplicity of transition from the full complex resistance to the active resistance, the resistance of the scattering inductance and the mutual inductance depending on the number of turns Table 1 lists the values of these magnitudes, which were used in the research of the asynchronous motor operation with nonsymmetrical stator windings.

Table 2

Values of active, inductive, complex resistance of stator phase, resistance of mutual stator and rotor inductance at different values of complex resistance

\begin{tabular}{|c|c|c|c|c|c|c|}
\hline$z_{1} / z_{\text {Inom }}$ & $z_{l}, \mathrm{OM}_{\mathrm{M}}$ & $w_{1}$ & $\left(w_{l}\right)^{2}$ & $r_{l}, \mathrm{OM}_{\mathrm{M}}$ & $x_{1}, \mathrm{OM}_{\mathrm{M}}$ & $x_{\mu}, \mathrm{OM}_{\mathrm{M}}$ \\
\hline 1 & 0.751 & 1 & 1 & 0.5 & 0.56 & 0.559 \\
\hline 0.9 & 0.676 & 0.934 & 0.872 & 0.467 & 0.489 & 0.547 \\
\hline 0.85 & 0.639 & 0.9 & 0.81 & 0.45 & 0.454 & 0.54 \\
\hline 0.8 & 0.601 & 0.864 & 0.746 & 0.432 & 0.418 & 0.534 \\
\hline 0.72 & 0.537 & 0.8 & 0.64 & 0.4 & 0.358 & 0.522 \\
\hline
\end{tabular}

The established adequacy in values in Table 2 terminate the construction of the simulation model for performing the research of the electromagnetic processes in the asynchronous motor with nonsymmetrical windings..

\section{RESEARCH OF THE EFFECT OF INTER-TURN SHORT-CIRCUITS ON THE TORQUE PULSATION ON THE MOTOR SHAFT AND PHASE CURRENTS' UNBALANCE}

Methods for performing the studies of the effect of various forms of inter-turns shortcircuits on the motor parameters includes parameters' modeling of the operating stator, simulations of short-circuiting, first only on a single phase $A$ and then a simultaneous shortcircuit on two phases of the stator winding: during the constant short-circuiting of the winding turns of phase $A$ (when the winding resistance is decreased to $80 \%$ versus the nominal value and two cases in addition, when the resistance decrease of phase $B$ winding occurs). For the reduced variants of the winding failures the values of the main parameters are determined in case of the asynchronous motor for the symmetrical mode (of the operating stator), at decreasing complex resistance of phase $A$ by $20 \%$ during permanent complex resistance of phase $B$, at a decrease in the complex resistance of phase $A$ by $20 \%$ and a simultaneous decrease in the complex resistance of phase B by 10 and $20 \%$. The results of modeling for various modes of the motor operation are listed in Tables 3 and 4.

Table 3

Modeling results of asynchronous motor operation in idle-run mode at various kinds of phase failures of the stator windings

\begin{tabular}{|l|c|c|c|c|}
\hline \multirow{2}{*}{ Parameter } & \multirow{2}{*}{$\begin{array}{c}\text { Failure-free } \\
\text { stator }\end{array}$} & \multicolumn{2}{|c|}{$\begin{array}{c}\text { Number of unimpared turns } \\
\text { of phase } A \text { winding - 80\% }\end{array}$} \\
\cline { 3 - 5 } & & \multicolumn{2}{|c|}{$\begin{array}{c}\text { Number of unimpared turns } \\
\text { of phase } B \text { winding }\end{array}$} \\
\cline { 3 - 5 } & & $100 \%$ & $90 \%$ & $80 \%$ \\
\hline Rotor spinning frequency $n$, rot/min & 1498 & 1498 & 1498 & 1498 \\
\hline Average electromagnetic torque $T_{\text {midlle }}, \mathrm{H} \cdot \mathrm{m}$ & 0.3804 & 0.3822 & 0.3787 & 0.3776 \\
\hline Maximum electromagnetic torque $T_{\text {max }}, \mathrm{H} \cdot \mathrm{m}$ & 0.3804 & 1.8997 & 1.6979 & 1.8895 \\
\hline Minimum electromagnetic torque $T_{\text {min }}, \mathrm{H} \cdot \mathrm{m}$ & 0.3804 & -1.134 & -0.941 & -1.1344 \\
\hline Torque ripple frequency $f_{\text {puls }}, \mathrm{Hz}$ & 0 & 100 & 100 & 100 \\
\hline Phase $A$ root-mean-square current of stator $I_{I A}, \mathrm{~A}$ & 9.403 & 11.553 & 11.99 & 12.456 \\
\hline Phase $B$ root-mean-square current of stator $I_{I A}, B$ & 9.403 & 9.805 & 10.923 & 12.244 \\
\hline Phase $C$ root-mean-square current of stator $I_{I C}, B$ & 9.403 & 9.974 & 10.242 & 10.513 \\
\hline Electromagnetic torque ripple factor $k_{\text {puls }} T, \%$ & 0 & 396.91 & 348.35 & 400.41 \\
\hline Unbalance factor of stator phase currents $k_{\text {unballI }}, \%$ & 0 & 18.59 & 18.59 & 20.664 \\
\hline
\end{tabular}


In Tables 3, 4, torque ripple is calculated using (12)

$$
k_{p M}=\left(\left(T_{\max }-T_{\min }\right) / T_{\text {midle }}\right) \cdot 100 \%,
$$

where $T_{\max }$ is the max torque value; $\mathrm{H} \cdot \mathrm{M} ; T_{\min }$ is the min torque value; $\mathrm{H} \cdot \mathrm{M} ; T_{\min }$ is the is the average torque value.

Table 4

Modeling results of asynchronous motor in nominal mode at different types of phase failures of stator windings

\begin{tabular}{|c|c|c|c|c|}
\hline \multirow{3}{*}{ Parameter } & \multirow{3}{*}{$\begin{array}{c}\text { Failure-free } \\
\text { stator }\end{array}$} & \multirow{2}{*}{\multicolumn{3}{|c|}{$\begin{array}{l}\text { Number of unimpaired } \\
\text { turns of phase } A \text { winding } \\
80 \% \\
\text { Number of unimpaired } \\
\text { turns of phase } B \text { winding }\end{array}$}} \\
\hline & & & & \\
\hline & & $100 \%$ & $90 \%$ & $80 \%$ \\
\hline Rotor spinning frequency $n$, rot $/ \mathrm{min}$ & 1450 & 1450 & 1450 & 1450 \\
\hline Average electromagnetic torque $T_{\text {middle }}, \mathrm{H} \cdot \mathrm{m}$ & 72.443 & 72.878 & 73.02 & 73.24 \\
\hline Maximum electromagnetic torque $T_{\max }, \mathrm{H} \cdot \mathrm{m}$ & 72.443 & 74.938 & 74.56 & 75.01 \\
\hline Minimum electromagnetic torque $T_{\min }, \mathrm{H} \cdot \mathrm{m}$ & 72.443 & 68.886 & 69.56 & 69.48 \\
\hline Torque ripple frequency $f_{\text {puls }}, \mathrm{Hz}$ & 100 & 100 & 100 & 100 \\
\hline Phase $A$ root-mean-square current of stator $I_{l A}, \mathrm{~A}$ & 21.879 & 25.566 & 25.52 & 25.39 \\
\hline Phase $B$ root-mean-square current of stator $I_{l A}, B$ & 21.879 & 20.29 & 23.34 & 25.12 \\
\hline Phase $C$ root-mean-square current of stator $I_{I C}, B$ & 21.879 & 20.318 & 21.9 & 21.339 \\
\hline Electromagnetic torque ripple factor $k_{p u l s T}, \%$ & 0 & 4.152 & 3.424 & 3.777 \\
\hline Unbalance factor of stator phase currents $k_{\text {unball }}, \%$ & 0 & 24.114 & 16.53 & 18.58 \\
\hline
\end{tabular}

The unbalance factor of stator phase currents is determined using the following formula

$$
k_{\text {unb } 1}=\left(\left(I_{S \max }-I_{S \min }\right) / I_{S s y m . m o d e}\right) \cdot 100 \%,
$$

where $I_{S \max }$ is the max value of the stator phase current, $A ; I_{\text {Smin }}$ is the min value of the stator phase current, $A ; I_{\text {Ssym.mode }}$ is the value of the phase current at the symmetrical mode, A.

The analysis of the modeling results from Tables 3, 4 show that the torque ripple for the nominal mode of the electric motor operation is substantially lower than that for the idle-run mode. In this context, to perform the estimation of the results obtained, the dependence was created of the change in the electromagnetic torque ripple factor at the decreased value of the complex resistance of the stator phase $A$ by $20 \%$ versus the degree of decrease of phase $B$ complex resistance only for the idle-run mode. During the dependence creation, phase $B$ complex resistance was modified from the nominal value of $100 \%(1,0)$ to $80 \%(0,8)$ with a step of $5 \%(0,5)$ (Fig. 2). According to the results of Tables 3, 4, the graphs were also plotted exhibiting the change in the unbalance factor of the stator phase currents at a constant value of $80 \%$ of phase $A$ complex resistance versus the nominal induced by the inter-turn short-circuit, depending on the decrease in resistance of the stator phase $B$ winding from $100 \%$ (1.0) (unfaulted) to $80 \%(0.8)$ at a step of $5 \%(0.5)$ for the idle-run mode and nominal (Fig. 3).

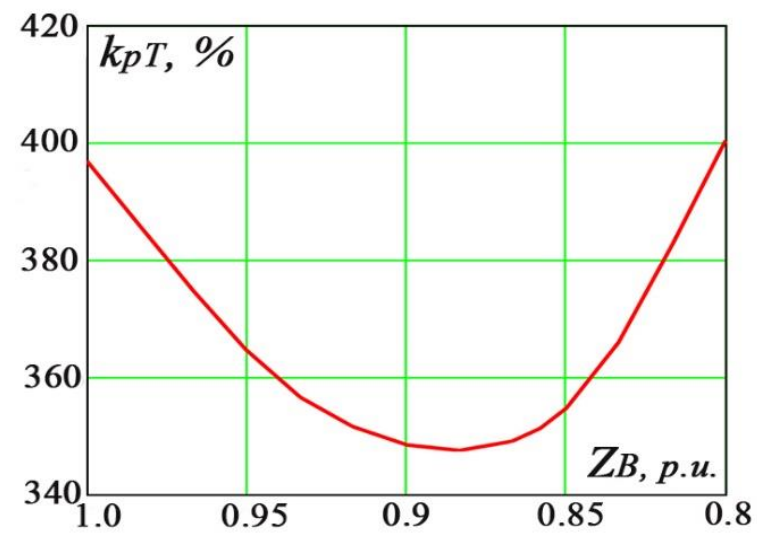

Fig. 2. Dependence of electromagnetic ripple factor $k p T, \%$ on the change in phase $A$ complex resistance by $20 \%$ and simultaneous change in phase $B$ complex resistance of stator in idle-run mode.

It follows from Fig. 2 that the most significant changes occur in the electromagnetic torque pulsation during the change in the complex resistance of the stator phases in the 
idle-run mode of the electric motor operation. The unbalance factor of the stator phase current (Fig. 3) during the change both in active and complex resistances of one of the motor phases changes insignificantly.

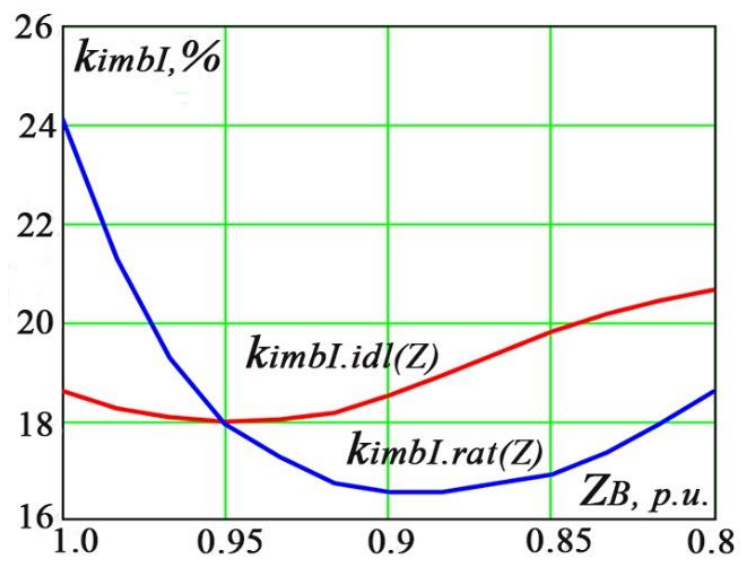

Fig. 3. Dependence of unbalance factor of stator phase currents on the change in phase $A$ resistance by $20 \%$ and in idlerun mode simultaneous change in phase $B$ complex resistance of stator in idle-run mode $\boldsymbol{k}_{\text {imbI.idl }}$ and nominal mode $\boldsymbol{k}_{\text {imbI.rat }}$

In addition, Fig. 2 shows that changes in the torque pulsation coefficient for the idle-run mode of the motor operation and the unbalance factor of the stator phase currents (see Fig 3) for the nominal mode have a similar parabolic character during the change in the complex resistance of phase $B$. Unlike the inter-turn short-circuit at a single stator phase, where the linear character dependence is observed, for the inter-turn shortcircuit on two phases the initial decrease in the ripple factor is typical at an increase in the failure degree on the second phase followed by an abrupt increase, which is especially characteristic for the idle-run mode (Fig. 2). The dependence like this can be attributed to the fact that during the complex resistance change on the faulted phase $B$ from the nominal value by 5$10 \%$, an intermediate 'levelling' occurs of the complex resistances of the phase windings at the expense of increasing the inductive component of the winding resistance. Upon reaching the decrease in the complex resistance of phase $B$ by over $10 \%$ from nominal, the inductive resource of compensation of the phase complex resistance becomes exhausted, which sharply increases the electromagnetic torque pulsations in the idle-run mode and the unbalance factor of the stator phase currents in the nominal mode.

In addition, it follows from Figs. 2, 3 that both of the torque ripple factor and unbalance factor of the stator phase currents depend more on the change in the phase $A$ complex resistance, than on the change in the active resistance.

It is clear from the dependence character obtained that it is not quite correct to use the torque pulsation on the motor shaft and, hence, ether the vibrodiagnosis methods upon establishing the type and degree of the inter-turn short-circuit.

\section{EFFECT STUDY OF INTER-TURN SHORT-CIRCUIT ON MECHANICAL AND OPERATIONAL CHARACTERISTICS}

The researches of the change in the mechanical and operation motor characteristics upon the inter-turn shirt-circuits are carried out for the following cases: the failure-free stator; upon the inter-turn short-circuit at phase $A$ by $20 \%$ with the unfaulted phase $B$; upon the interturn short-circuit at phase $A$ by $20 \%$ with a simultaneous inter-turn short-circuit at the stator phase $B$, considering that, first, $10 \%$ and then $20 \%$ of the winding turns of this phase were short-circuited.

During the studies performed in the model it is accepted that as a result of the inter-turn shortcircuit in the phases of the corresponding windings of $10-20 \%$ of the general number of the phase turns, the complex resistance of the stator winding changes to 90 and $80 \%$ of the nominal (calculated) value.

Modeling of the processes taking place upon the inter-turn short-circuits of the stator winding was performed for the fixed frequencies of the motor rotor spinning using the aforementioned simulation model. The modeling results are listed in Tables 5-8.

Table 5. Modeling results of torque dependence on the motor shaft $(T)$ and of power output $\left(P_{2}\right)$ on rotor spinning frequency $(n)$

\begin{tabular}{|c|c|c|c|c|}
\hline \multirow{3}{*}{$\begin{array}{c}n, \\
\text { rot/min }\end{array}$} & \multirow{2}{*}{$\begin{array}{c}T, \mathrm{H} \cdot \mathrm{m} \\
\text { Failure-free stator }\end{array}$} & $\begin{array}{c}\text { Number of phase } A \\
\text { unfaulted winding turns }-80 \%\end{array}$ & \multirow{2}{*}{ Failure-free stator } & $\begin{array}{c}\text { Number of phase } A \text { unfaulted } \\
\text { winding turns }-80 \%\end{array}$ \\
\cline { 3 - 5 } & $\begin{array}{c}\text { Number of phase } B \\
\text { unfaulted winding turns }\end{array}$ & $\begin{array}{c}\text { Number of phase } B \\
\text { unfaulted winding turns }\end{array}$ \\
\hline
\end{tabular}


Table 5 continuation

\begin{tabular}{|c|c|c|c|c|c|c|c|c|}
\hline & & $100 \%$ & $90 \%$ & $80 \%$ & & $100 \%$ & $90 \%$ & $80 \%$ \\
\hline 1425.7 & 100.865 & 101.823 & 102.191 & 102.633 & 15.059 & 15.202 & 15.257 & 15.323 \\
\hline 1440.8 & 83.132 & 84.133 & 84.65 & 84.206 & 12.54 & 12.694 & 12.772 & 12.705 \\
\hline 1450.0 & 72.443 & 72.878 & 73.023 & 73.24 & 11.0 & 11.066 & 11.088 & 11.121 \\
\hline 1470.8 & 42.923 & 43.137 & 43.208 & 43.191 & 6.611 & 6.644 & 6.655 & 6.655 \\
\hline 1485.8 & 20.573 & 20.573 & 20.573 & 20.607 & 3.201 & 3.201 & 3.201 & 3.201 \\
\hline 1488.3 & 16.727 & 16.727 & 16.727 & 16.701 & 2.607 & 2.607 & 2.607 & 2.607 \\
\hline 1490.8 & 12.824 & 12.824 & 12.824 & 12.804 & 2.002 & 2.002 & 2.002 & 2.002 \\
\hline 1493.3 & 8.793 & 8.793 & 8.793 & 8.806 & 1.375 & 1.375 & 1.375 & 1.375 \\
\hline 1494.8 & 6.458 & 6.458 & 6.458 & 6.458 & 1.012 & 1.012 & 1.012 & 1.012 \\
\hline 1496.4 & 3.8596 & 3.8596 & 3.8596 & 3.8596 & 0.605 & 0.605 & 0.605 & 0.605 \\
\hline 1497.9 & 1.473 & 1.473 & 1.473 & 1.461 & 0.231 & 0.231 & 0.231 & 0.231 \\
\hline 1498 & 0 & 0 & 0 & 0 & 0 & 0 & 0 & 0 \\
\hline
\end{tabular}

Table 6

Modeling results of dependency of total power $(S)$ and reactive power $\left(Q_{1}\right)$, consumed from circuit from rotor spinning frequency $(n)$

\begin{tabular}{|c|c|c|c|c|c|c|c|c|}
\hline \multirow{4}{*}{$\begin{array}{c}n, \\
\mathrm{rot} / \mathrm{min}\end{array}$} & \multicolumn{4}{|c|}{$S, \mathrm{~B} \cdot \mathrm{A}$} & \multicolumn{4}{|c|}{$Q_{l}$, B·Ap } \\
\hline & \multirow{3}{*}{$\begin{array}{l}\text { Failure-free } \\
\text { stator }\end{array}$} & \multirow{2}{*}{\multicolumn{3}{|c|}{$\begin{array}{c}\text { Number of phase } A \text { unfaulted } \\
\text { winding turns - 80\% } \\
\begin{array}{c}\text { Number of phase } B \text { unfaulted } \\
\text { winding turns }\end{array}\end{array}$}} & \multirow{3}{*}{$\begin{array}{c}\text { Failure-free } \\
\text { stator }\end{array}$} & \multirow{2}{*}{\multicolumn{3}{|c|}{\begin{tabular}{|c|} 
Number of phase $A$ unfaultec \\
winding turns - $80 \%$ \\
Number of phase $B$ \\
unfaulted winding turns
\end{tabular}}} \\
\hline & & & & & & & & \\
\hline & & $100 \%$ & $90 \%$ & $80 \%$ & & $100 \%$ & $90 \%$ & $80 \%$ \\
\hline 1425.7 & 20.268 & 21.218 & 21.964 & 22.651 & 10.545 & 11.643 & 12.412 & 13.062 \\
\hline 1440.8 & 16.554 & 17.391 & 18.006 & 18.534 & 8.585 & 9.49 & 10.15 & 10.661 \\
\hline 1450.0 & 14.44 & 15.128 & 15.567 & 15.804 & 7.513 & 8.301 & 8.877 & 9.067 \\
\hline 1470.8 & 9.803 & 10.485 & 11.232 & 11.676 & 6.528 & 7.32 & 8.183 & 8.678 \\
\hline 1485.8 & 7.091 & 7.726 & 8.845 & 9.461 & 6.137 & 6.782 & 7.903 & 8.537 \\
\hline 1488.3 & 6.782 & 7.355 & 8.559 & 9.221 & 6.123 & 6.678 & 7.878 & 8.555 \\
\hline 1490.8 & 6.527 & 7.257 & 8.254 & 8.896 & 6.121 & 6.822 & 7.803 & 8.449 \\
\hline 1493.3 & 6.447 & 7.171 & 7.938 & 8.885 & 6.237 & 6.929 & 7.677 & 8.632 \\
\hline 1494.8 & 6.333 & 7.138 & 7.882 & 8.81 & 6.204 & 6.988 & 7.722 & 8.653 \\
\hline 1496.4 & 6.282 & 6.919 & 7.543 & 8.359 & 6.223 & 6.846 & 7.422 & 8.276 \\
\hline 1497.9 & 6.223 & 6.912 & 7.306 & 7.979 & 6.199 & 6.883 & 7.269 & 7.943 \\
\hline 1498 & 6.206 & 6.905 & 7.294 & 7.747 & 6.204 & 6.799 & 7.287 & 7.737 \\
\hline
\end{tabular}

Таблица 7

Modeling results of active power $\left(P_{I}\right)$ consumed from circuit and stator average current $\left(I_{l m i d}\right)$ on rotor spinning frequency $(n)$

\begin{tabular}{|c|c|c|c|c|c|c|c|c|}
\hline \multirow{4}{*}{$\begin{array}{c}n, \\
\mathrm{rot} / \mathrm{min}\end{array}$} & \multicolumn{4}{|c|}{$P_{l}, \mathrm{\kappa W}$} & \multicolumn{4}{|c|}{$I_{\text {Imid }}, \mathrm{A}$} \\
\hline & \multirow{3}{*}{$\begin{array}{l}\text { Failure-free } \\
\text { stator }\end{array}$} & \multirow{2}{*}{\multicolumn{3}{|c|}{$\begin{array}{c}\text { Number of phase } A \text { unfaulted } \\
\text { winding turns - } 80 \% \\
\begin{array}{c}\text { Number of phase } B \text { unfaulted } \\
\text { winding turns }\end{array}\end{array}$}} & \multirow{3}{*}{$\begin{array}{l}\text { Failure-free } \\
\text { stator }\end{array}$} & \multirow{2}{*}{\multicolumn{3}{|c|}{$\begin{array}{c}\text { Number of phase } A \text { unfaulted } \\
\text { winding turns - } 80 \% \\
\text { Number of phase } B \text { unfaulted } \\
\text { winding turns }\end{array}$}} \\
\hline & & & & & & & & \\
\hline & & $100 \%$ & $90 \%$ & $80 \%$ & & $100 \%$ & $90 \%$ & $80 \%$ \\
\hline 1425.7 & 17.309 & 17.739 & 18.12 & 18.506 & 30.71 & 32.149 & 33.278 & 34.32 \\
\hline 1440.8 & 14.153 & 14.574 & 14.873 & 15.161 & 25.082 & 26.351 & 27.282 & 28.082 \\
\hline 1450.0 & 12.332 & 12.647 & 12.788 & 12.944 & 21.879 & 22.058 & 23.586 & 23.946 \\
\hline 1470.8 & 7.313 & 7.507 & 7.694 & 7.811 & 14.853 & 15.887 & 17.018 & 17.69 \\
\hline 1485.8 & 3.553 & 3.701 & 3.971 & 4.078 & 10.744 & 11.706 & 13.402 & 14.335 \\
\hline 1488.3 & 2.916 & 3.082 & 3.347 & 3.439 & 10.275 & 11.143 & 12.968 & 13.971 \\
\hline 1490.8 & 2.265 & 2.475 & 2.691 & 2.784 & 9.989 & 10.996 & 12.356 & 13.479 \\
\hline 1493.3 & 1.631 & 1.846 & 2.016 & 2.106 & 9.768 & 10.865 & 11.942 & 13.462 \\
\hline 1494.8 & 1.273 & 1.456 & 1.576 & 1.656 & 9.596 & 10.845 & 11.492 & 13.349 \\
\hline 1496.4 & 0.861 & 1.003 & 1.104 & 1.17 & 9.518 & 10.484 & 11.428 & 12.665 \\
\hline 1497.9 & 0.547 & 0.628 & 0.736 & 0.75 & 9.429 & 10.473 & 11.069 & 12.089 \\
\hline 1498 & 0.156 & 0.285 & 0.328 & 0.384 & 9.403 & 10.467 & 11.052 & 11.738 \\
\hline
\end{tabular}


Table 8

Modeling dependences of coefficient of efficiency $(\eta)$ and power coefficient $(\gamma)$ on rotor spinning frequency $(n)$

\begin{tabular}{|c|c|c|c|c|c|c|c|c|}
\hline \multirow{4}{*}{$\begin{array}{l}n, \\
\mathrm{rot} / \mathrm{min}\end{array}$} & \multicolumn{4}{|c|}{$\eta$, relative units } & \multicolumn{4}{|c|}{$\gamma$, relative units } \\
\hline & \multirow{3}{*}{$\begin{array}{l}\text { Failure-free } \\
\text { stator }\end{array}$} & \multirow{2}{*}{\multicolumn{3}{|c|}{$\begin{array}{l}\text { Number of phase } A \text { unfaulted } \\
\text { winding turns - } 80 \% \\
\begin{array}{c}\text { Number of phase } B \text { unfaulted } \\
\text { winding turns }\end{array}\end{array}$}} & \multirow{3}{*}{$\begin{array}{l}\text { Failure-free } \\
\text { stator }\end{array}$} & \multirow{2}{*}{\multicolumn{3}{|c|}{$\begin{array}{c}\text { Number of phase } A \text { unfaulted } \\
\text { winding turns - } 80 \% \\
\begin{array}{c}\text { Number of phase } B \text { unfaulted } \\
\text { winding turns }\end{array} \\
\end{array}$}} \\
\hline & & & & & & & & \\
\hline & & $100 \%$ & $90 \%$ & $80 \%$ & & $100 \%$ & $90 \%$ & $80 \%$ \\
\hline 1425.7 & 0.87 & 0.857 & 0.842 & 0.828 & 0.854 & 0.836 & 0.825 & 0.817 \\
\hline 1440.8 & 0.886 & 0.836 & 0.852 & 0.838 & 0.855 & 0.838 & 0.826 & 0.818 \\
\hline 1450.0 & 0.892 & 0.875 & 0.867 & 0.859 & 0.854 & 0.836 & 0.821 & 0.819 \\
\hline 1470.8 & 0.904 & 0.885 & 0.865 & 0.852 & 0.746 & 0.716 & 0.685 & 0.669 \\
\hline 1485.8 & 0.901 & 0.865 & 0.806 & 0.785 & 0.501 & 0.479 & 0.538 & 0.431 \\
\hline 1488.3 & 0.894 & 0.846 & 0.779 & 0.758 & 0.43 & 0.419 & 0.391 & 0.373 \\
\hline 1490.8 & 0.884 & 0.809 & 0.744 & 0.719 & 0.347 & 0.341 & 0.326 & 0.313 \\
\hline 1493.3 & 0.843 & 0.745 & 0.682 & 0.653 & 0.253 & 0.227 & 0.254 & 0.237 \\
\hline 1494.8 & 0.795 & 0.695 & 0.642 & 0.611 & 0.201 & 0.204 & 0.2 & 0.188 \\
\hline 1496.4 & 0.703 & 0.603 & 0.548 & 0.517 & 0.137 & 0.145 & 0.139 & 0.14 \\
\hline 1497.9 & 0.419 & 0.368 & 0.314 & 0.308 & 0.078 & 0.081 & 0.09 & 0.094 \\
\hline 1498 & 0 & 0 & 0 & 0 & 0.025 & 0.041 & 0.045 & 0.05 \\
\hline
\end{tabular}

To define the useful power in Table 5, the following expression is used

$$
P_{2}=T \cdot \omega
$$

where $T$ is the motor shaft torque, $\mathrm{H} \cdot \mathrm{M}$; and $\omega$ is the rotor spinning frequency of the motor, $\mathrm{rad} / \mathrm{s}$.

The rotor spinning frequency of the motor with a number of pole pairs $p=2$ is determined using the following expression

$$
\omega=n / 9.55,
$$

where $n$ is the rotor spinning frequency of the motor.

The nominal reactive power in Table 6 is determined using the following expression

$$
\begin{aligned}
& Q_{1}=-\left(u_{s \alpha} \cdot\left(i_{s \beta}-i_{s \gamma}\right)+u_{s \beta} \cdot\left(i_{s \gamma}-i_{s \alpha}\right)+\right. \\
& \left.+u_{s \gamma} \cdot\left(i_{s \alpha}-i_{s \beta}\right)\right) / \sqrt{3} .
\end{aligned}
$$

Nominal total power consumed of the circuit in Table 6 is determined using the following expression

$$
S_{1}=u_{s \alpha} \cdot i_{s \alpha}+u_{s \beta} \cdot i_{s \beta}+u_{s \gamma} \cdot i_{s \gamma} .
$$

The value of nominal active power consumed of the circuit in Table 7 is defined using (18)

$$
P_{1}=\sqrt{\left(S_{1}\right)^{2}-\left(Q_{1}\right)^{2}}
$$

According to the modeling results from Table 5 , the mechanical characteristics are plotted as shown in Fig. 4. Using the data of Tables 5, 6, the dependences of total power that is consumed of the circuit using the nominal value of the useful power $P_{2}^{*}=P_{2} / P_{2 \text { rat }}$ (Fig. 5).

Tables 5 and 7 were used to create the dependences of the nominal value of the active power consumed of the circuit $P_{1}^{*}=P_{1} / P_{1 r a t}$ from the nominal value of the useful power $P_{2}^{*}=P_{2} / P_{2 r a t}$ (Fig. 6) and dependence of the average nominal value of the stator phase current $I_{1 \text { mid }}^{*}=I_{1 \text { mid }} / I_{1 \text { mid.rat }}$ from the nominal value of the useful power $P_{2}^{* \prime}=P_{2} / P_{2 \text { rat }}$ (Fig. 7).

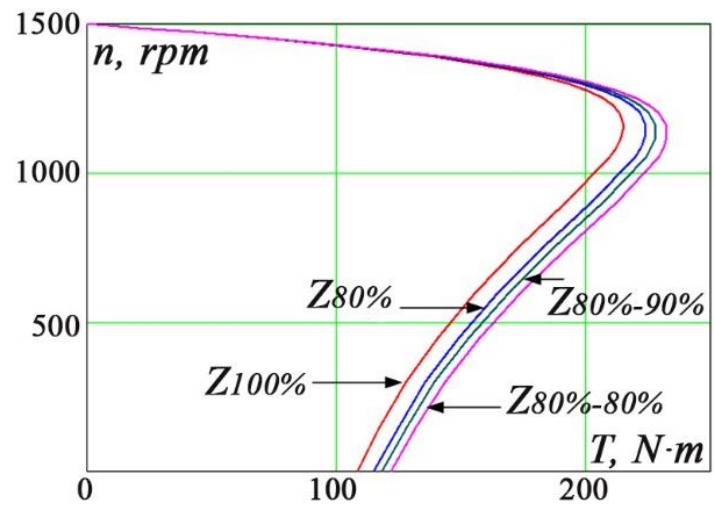

Fig. 4. Motor mechanical characteristics 


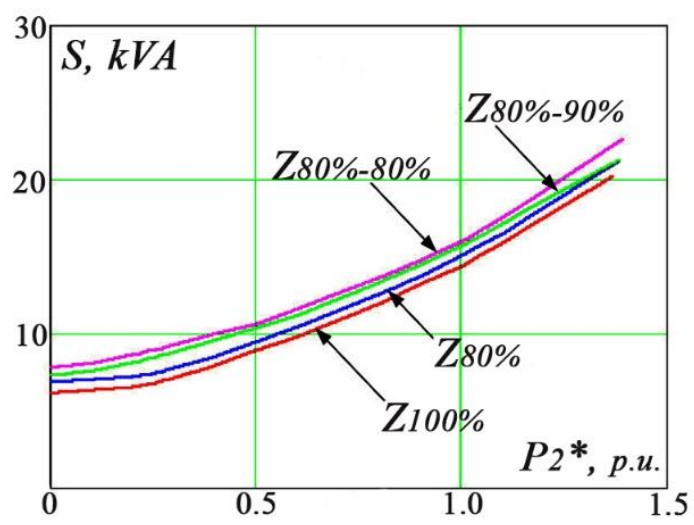

Fig. 5. Dependence of total power consumed of circuit $(S)$ on relative value of useful power $\left(P_{2} *\right)$

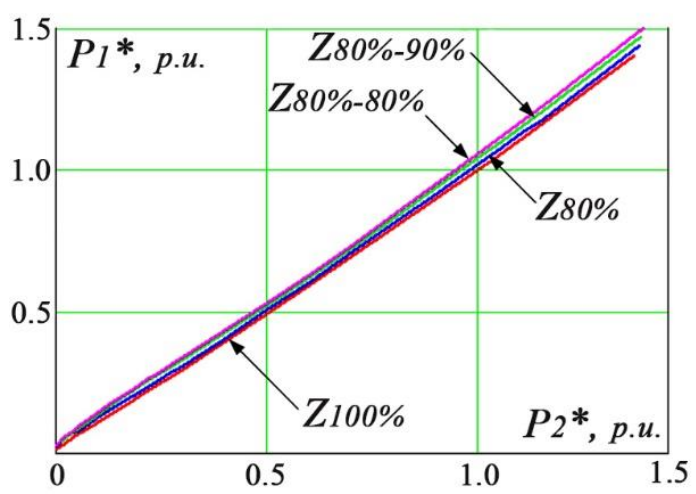

Fig. 6. Dependences of relative value of active power $\left(P_{1}^{*}\right)$ consumed of circuit on relative value of useful power $\left(P_{2} *\right)$

In accordance with the results of Tables 5, 8, the dependences of the coefficient of efficiency (Fig. 8) and power factor (Fig. 9) on the nominal value of useful power $P_{2}^{*}=P_{2} / P_{2 r a t}$.

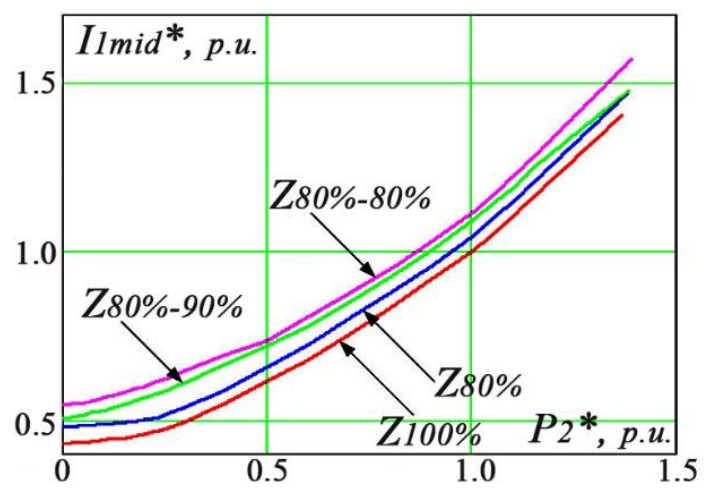

Fig. 7. Dependences of average relative value of stator phase current $\left(I_{1 m i d}{ }^{*}\right)$ on useful power $\left(P_{2} *\right)$ value

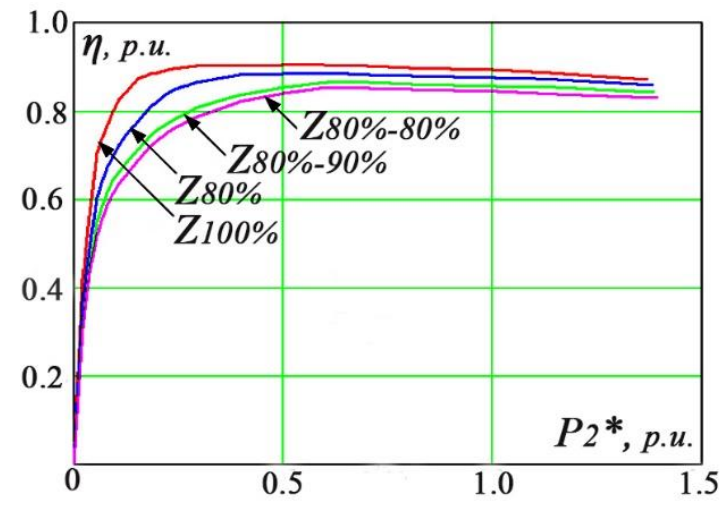

Fig. 8. Dependence of coefficient of efficiency $(\eta)$ on relative value of useful power $\left.\underline{\left(P_{2}\right.} *\right)$

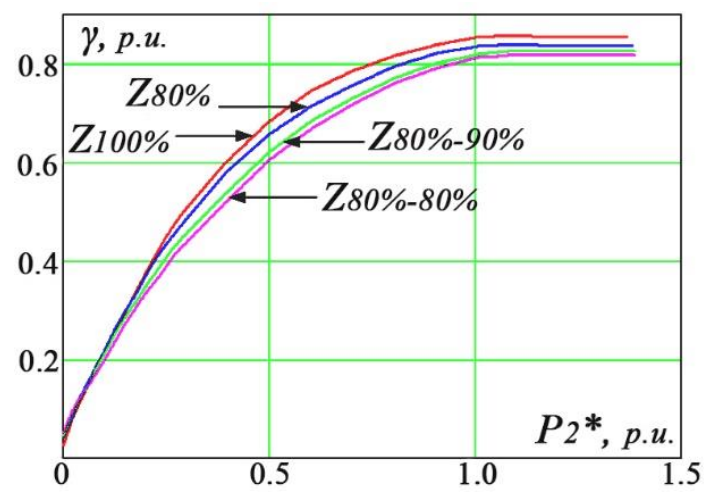

Fig. 9. Dependence of power factor $(\gamma)$ on relative value of useful power $\left(P_{2} *\right)$

The analysis of the modeling results with the account for the dependences obtained shows (Figs. 4-9) that with an increase in the level (degree) of the inter-turn short-circuit at the second phase, compared to the inter-turn shortcircuit at a single phase:

- the value of the critical torque increases (Fig. 4);

- the total and active powers that are consumed from the circuit (Figs. 5, 6) to create one and the same frequency of the rotor spinning, increase;

- the average value of the current in the faulted stator phase enhances (Fig. 7);

- the coefficient of efficiency (Fig. 8) and the motor power factor (Fig. 9) decrease with the maximum coefficient of efficiency being shifted to the area of the higher loads.

\section{CONCLUSIONS}

This work offers the complex approach to the study of the effect of the inter-turn short-circuit of different types on the parameters and characteristics of the asynchronous motors. To solve this problem: 
- the mathematical model of the asynchronous motor was selected to allow modeling the operation of the asynchronous motor with nonsymmetrical windings;

- the motor parameters were verified and corrected to obtain the agreement of the modeling results with the motor calculated parameters;

- the effect was studied of the inter-turn shortcircuit at a single phase of the stator winding and at two-phase stator simultaneously on the electromagnetic torque ripple factor and the unbalance factor of the stator phase currents. The studies are performed on assumption that resulting from the inter-turn short-circuiting, the winding active resistance and its complex resistances can change. The research results showed that the highest value of the torque ripple factor is exhibited in the idle-run mode during the change in the complex resistance (at a $20 \%$ inter-turn short-circuit in the case of a single phase failure, the torque ripple factor was 264 $\%)$. The unbalance factor of the stator phase currents also increased upon the change in the complex resistance, however, having close values for the idle-run mode and for the nominal mode ( $16.5 \%$ for the idle-run mode and $16.2 \%$ for the nominal mode);

- for the inter-turn short-circuit of a single phase a linear dependence is determined for increasing the electromagnetic ripple factor and the unbalance factor of the stator phase currents on the value of the change in the complex resistance value of the stator winding (on the failure degree);

- the studies performed aimed at the effect of the inter-turn short-circuit on the mechanic characteristics showed that with an increase in the inter-turn short-circuit up to $20 \%$, at the second phase for the two-phase failure of the winding, the motor critical moment increases by $2 \%$, which is also accompanied by the motor starting torque increase;

- the dependence is obtained to establish the connection between the torque pulsation factor and the unbalance factor of the stator phase currents with respect to the change in the phase $A$ and phase $B$ complex resistance at a simultaneous inter-turn short-circuit at two phases of the motor winding;

- in the process of the studies, it was established that at the motor nominal operational mode, the $20 \%$-increase in the inter-turn shortcircuit, at each phase simultaneously at a twophase winding failure, causes the increase in the total power, that is consumed from the circuit by $7.1 \%$, the active - by $4.2 \%$, and the average stator phase current - by $7.2 \%$. This decreases the coefficient of efficiency by $4.78 \%$ and in the power factor by $3.2 \%$.

The results of this work are the issue of the day in terms of selection of the diagnostic method for the inter-turn short-circuit in the stator winding, when creating the efficient diagnostic system used in the asynchronous motors as part of the drives of the transport electric equipment.

\section{Литература (References)}

[1] Lovska A., Fomin O. A New Fastener To Ensure The Reliability Of A Passenger Car Body On A Train Ferry. Acta Polytechnica, 2020, vol. 60, no. 6, pp. 478-485. Available at: https://doi.org/10.14311/AP.2020.60.0478

[2] Merizalde Y., Hernandez-Callejo L., DuquePerez O. State of the art and trends in the monitoring, detection and diagnosis of failures in electric induction motors. Energies, 2017, vol. 10 , no. 7, pp. 1056. Available at: https://doi.org/10.3390/en10071056.

[3] Mairte J., Gaboury S.,Bbouchard B., Bouzouane, A. A new computational method for stator faults recognition in induction machines based on hyper-volumes. In: 2015 IEEE International Conference on Electro/Information Technology (EIT). IEEE, 2015, pp. 216-220. Available at: https://doi.org/10. 1109/EIT.2015.7293343.

[4] Muxiri A. C., Bento F., Fonseca D. S. B., Cardoso A. J. M. Thermal analysis of an induction motor subjected to inter-turn shortcircuit failures in the stator windings. In: 2019 International Conference on Industrial Engineering, Applications and Manufacturing (ICIEAM). IEEE, 2019. pp. 1-5. Available at: https://doi.org/10.1109/ICIEAM.2019.8743076.

[5] Bento F., Adouni A., Muxiri A. C., Fonseca D. S., Marques Cardoso A. J.. On the risk of failure to prevent induction motors permanent damage, due to the short available time-todiagnosis of inter-turn short-circuit faults. IET Electric Power Applications, 2021, vol. 15, no. 1, pp. 51-62. Available at: https://doi.org/10.1049/elp2.12008.

[6] Asfani, D. A., Negara, I. M. Y., Hernanda, I. G. N. S., Fahmi, D., Muljadi, E., \& Nelms, R. M. (2020, October). Methods to Deter006Dine the Stator Inter-turn Short Circuit in an Induction Motor with Installed Rotor. In: 2020 IEEE Energy Conversion Congress and Exposition $(E C C E), 2020$, pp. 7-13. Available at: https://doi.org/10.1109/ECCE44975.2020.92360 $\underline{51}$. 
[7] Adouni A., J Marques Cardoso A. Thermal Analysis of Low-Power Three-Phase Induction Motors Operating under Voltage Unbalance and Inter-Turn Short Circuit Faults. Machines, 2021, vol. 9, no. 1, pp. 2-11. Available at: https://doi.org/10.3390/machines9010002

[8] Pietrowski W., Górny, K. Analysis of Torque Ripples of an Induction Motor Taking into Account a Inter-Turn Short-Circuit in a Stator Winding. Energies, 2020, vol. 13, no. 14, pp. 3626-3642. Available https://doi.org/10.3390/en13143626.

[9] Goolak S., Gerlici J., Gubarevych O., Lack T., Pustovetov M. Imitation Modeling of an InterTurn Short Circuit of an Asynchronous Motor Stator Winding for Diagnostics of Auxiliary Electric Drives of Transport Infrastructure. Communications - Scientific Letters of the University of Zilina, vol. 23 no. 2, pp. C65-C74. https://doi.org/10.26552/com.C.2021.2.C65-C74.

[10] Bouakoura M., Nait-Said M. S., Nait-Said N. Incipient Inter-Turn Short Circuit Fault Estimation Based on a Faulty Model Observer and ANN-Method for Induction Motor Drives //Recent Advances in Electrical \& Electronic Engineering (Formerly Recent Patents on Electrical \& Electronic Engineering), 2019, vol. 12, no. 4. pp. 374-383. Available at: https://doi.org/10.2174/235209651166618070511 $\underline{3021}$.

[11] Nabanita D., Sreedhar S., Zade N., Bhalerao O., Potdar P., Singh R. R. (2019, October). Inter turn Fault Analysis on Wound Rotor Induction Machine. In: IOP Conference Series: Materials Science and Engineering, 2019, vol. 623, no. 1, pp. 012016-012027. Available at: https://doi.org/10.1088/1757899X/623/1/012016..

[12] Singh G., Kumar T. C. A., Naikan V. N. A. Induction motor inter turn fault detection using infrared thermographic analysis. Infrared Physics \& Technology, 2016, no 77, pp. 277-282. Available https://doi.org/10.1016/j.infrared.2016.06.010.

[13] Kumar P., Isha, T. B. FEM based electromagnetic signature analysis of winding inter-turn short-circuit fault in inverter fed induction motor. CES Transactions on Electrical Machines and Systems, 2019, vol. 3 no. 3, pp. 309-315.

Available

at: https://doi.org/10.30941/CESTEMS.2019.00041.

[14] Hegde V., Sathyanarayana Rao M. G. Detection of stator winding inter-turn short circuit fault in induction motor using vibration signals by MEMS accelerometer. Electric Power Components and Systems, 2017, vol. 45, no. 13, pp. 1463-1473. Available at: https://doi.org/10.1080/15325008.2017.1358777
[15]Zaparoli I. O., Baccarini L. M. R., Lamim Filho P. C. M., Batista F. B.. Transient envelope current analysis for inter-turn short-circuit detection in induction motor stator. Journal of the Brazilian Society of Mechanical Sciences and Engineering, 2020, vol. 42, no. 2, pp. 97-108. Available at: https://doi.org/10.1007/s40430-0202188-7.

[16] Liu C., Xu L., Chen X. Fault feature extraction of rotor broken bar and stator winding inter-turn short circuit of asynchronous motors. In: Journal of Physics: Conference Series, 2019, vol. 1176, no 5, pp. 052045-052050. Available at: https://doi.org/10.1088/17426596/1176/5/052045.

[17] Pandarakone S. E., Mizuno Y., Nakamura H. Online Slight Inter-Turn Short-Circuit Fault Diagnosis Using the Distortion Ratio of Load Current in a Low-Voltage Induction Motor. IEEJ Journal of Industry Applications, 2018, vol. 7, no. 6, pp. 473-478. Available at: https://doi.org/10.1541/ieejjia.7.473.

[18] Bessam B., Menacer A., Boumehraz M., Cherif $\mathrm{H}$. Wavelet transform and neural network techniques for inter-turn short circuit diagnosis and location in induction motor. International Journal of System Assurance Engineering and Management, 2017, vol. 8, no. 1, pp. 478-488. Available at: https://doi.org/10.1007/s13198-0150400-4.

[19] Cherif H., Menacer A., Romary R., Pusca, R. Dispersion field analysis using discrete wavelet transform for inter-turn stator fault detection in induction motors. In: 2017 IEEE 11th International Symposium on Diagnostics for Electrical Machines, Power Electronics and Drives (SDEMPED), 2017, pp. 104-109. Available at: https://doi.org/10.1109/DEMPED.2017.8062341.

[20] Prasob K., Kumar N. P., Isha T. B. Inter-turn short circuit fault analysis of PWM inverter fed three-phase induction motor using Finite Element Method In: 2017 International Conference on Circuit, Power and Computing Technologies (ICCPCT). - IEEE, 2017, pp. 1-6. Available at: https://doi.org/10.1109/ICCPCT.2017.8074384.

[21] Mohamed M., Mohamed E., Mohamed A. A., Abdel-Nasser M., Hassan M. M. Detection of Inter Turn Short Circuit Faults in Induction Motor using Artificial Neural Network. In: 2020 26th Conference of Open Innovations Association (FRUCT), 2020, pp. 297-304. Available at: https: //doi.org/10.23919/FRUCT48808.2020.9087535.

[22] Gorobchenko O., Fomin O., Gritsuk I., Saravas V., Grytsuk Y., Bulgakom M., Volodarets M., Zinchenko D. Intelligent locomotive decision support system structure development and operation quality assessment. In: 2018 IEEE 3rd International 
Conference on Intelligent Energy and Power Systems (IEPS), 2018, pp. 239-243. Available at: https: //doi.org/10.1109/IEPS.2018.8559487

[23] Shavelkin, O. O., Kaplun, V. V., \& Shvedchykova, I. O. (2019). Error elimination for current control loop for multi-functional singlephase grid-connected inverter. Электротехника u электромеханика, 2019, no.4, pp. 35-40. Available at: https: //doi.org/10.20998/2074272X.2019.4.05.

[24] Liubarskyi B., Petrenko O., Shaida V., Maslii A. Analysis of optimal operating modes of the induction traction drives for establishing a

\section{About authors}
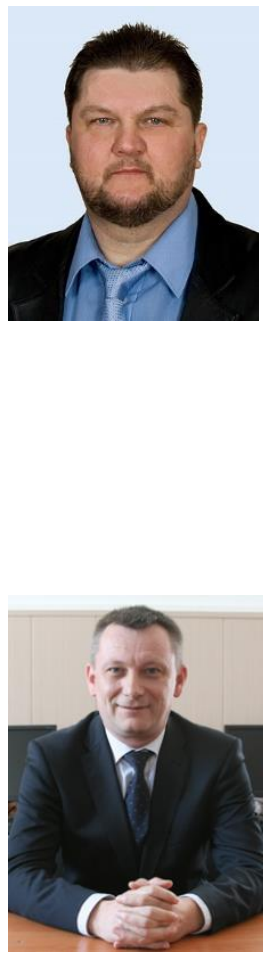

Губаревич Олег

Владимирович, к.т.Н., доцент, зав. каф. судовождения и эксплуатации технических систем на водном транспорте Дунайского института водного транспорта

Государственного университета инфраструктуры и технологий.

E-mail: oleg.gbr@ukr.net

\section{Гулак Сергей}

Александрович, к.т.н., старший преподаватель кафедры тягового подвижного состава Киевского института железнодорожного транспорта Государственного университета инфраструктуры и технологий.

E-mail:

sgoolak@gmail.com control algorithm over a semiconductor transducer. Eastern-European Journal of Enterprise Technologies, 2017, vol. 4, no. 8 (88), pp. 65-72. Available at: https://doi.org/10.15587/17294061.2017.109179.

[25] Ayyappan G. S., Ramesh Babu B., Srinivas K., Raja Raghavan M., Poonthalir R. Mathematical Modelling and IoT Enabled Instrumentation for Simulation \& Emulation of Induction Motor Faults. IETE Journal of Research, 2021, pp. 113. Available at: https://doi.org/10.1080/03772063.2021.1875272

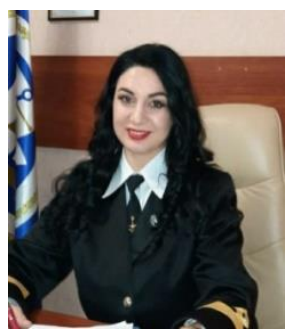

\author{
Даки Елена \\ Анатольевна, \\ д.т.н., доцент, директор \\ Дунайского института \\ водного транспорта \\ Государственного \\ университета \\ инфраструктуры и \\ технологий. \\ E-mail: \\ daki-olena@ukr.net
}

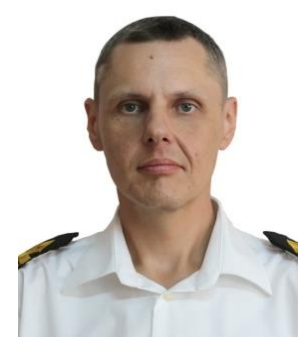

\section{Тришин Вячеслав} Валентинович,

старший преподаватель кафедры судовождения и эксплуатации технических систем на водном транспорте Дунайского института водного транспорта Государственного университета инфраструктуры и технологий. E-mail: trv.argent@gmail.com 